\title{
The trophic status of marine turtles as determined by stable isotope analysis
}

\author{
B. J. Godley ${ }^{1,2, *}$, D. R. Thompson ${ }^{1, * *}$, S. Waldron ${ }^{3}$, R. W. Furness ${ }^{1}$ \\ ${ }^{1}$ Division of Environmental and Evolutionary Biology, Graham Kerr Building, University of Glasgow, Glasgow G12 8QQ, \\ United Kingdom \\ ${ }^{2}$ Department of Veterinary Anatomy, University of Glasgow Veterinary School, Glasgow G61 1QH, United Kingdom \\ ${ }^{3}$ Scottish Universities Research and Reactor Centre, Scottish Technology Park, East Kilbride, Glasgow G75 OQU, \\ United Kingdom
}

\begin{abstract}
Stable isotope ratios of nitrogen and carbon were determined in bone collagen, egg proteins and keratin from epidermal carapace scutes of loggerhead Caretta caretta, green Chelonia mydas, and leatherback Dermochelys coriacea turtles from the Mediterranean Sea and the European Atlantic Ocean. Isotope ratios in proteins from loggerhead turtles indicate that this species occupies a higher trophic position than green turtles. Leatherback turtles are apparently intermediate in trophic status. Within loggerhead turtles, both isotope ratios correlated positively with body size, indicating a trend of increasing trophic level with age. Within the size range of green turtles sampled, there was apparently no change in trophic level in relation to body sire. In absolute terms, isotope signatures of egg proteins were markedly different from those of bone collagen. However, inter-specific differences in isotone values were consistent with those in bone protein. The luvvel application of this technuque to marine turtles generally confirmed dietary information collected conventionally in these species and has also afforded additional insights into shifts in diet and trophic status as turtles mature.
\end{abstract}

KEY WORDS: Feeding ecology - Caretta caretta - Chelonia mydas - Dermochelys coriacea - Mediterranean Carbon · Nitrogen

\section{INTRODUCTION}

In the Mediterranean, there are breeding populations of both green Chelonia mydas and loggerhead Caretta caretta turtles. It has been estimated that these populations number as few as 300 to 400 female green turtles and 2000 female loggerhead turtles nesting annually, and both species are considered regionally 'endangered' (Groombridge 1990). Green turtles nest in Turkey and Cyprus, with occasional small numbers nesting in Israel. Loggerhead turtles nest more widely; large breeding populations have been recorded in Greece, Turkey, Cyprus and Libya, with low levels of nesting found elsewhere (Broderick \& Godley 1996). In

'E-mail: b.godley@udcf.gla.ac.uk

- Present address: National Institute of Water \& Atmospheric Research, 301 Evans Bay Parade, Greta Point, PO Box 14-901. Kilbirnie, Wellington, New Zealand addition, although not known to reproduce in the region, leatherback turtles Dermochelys coriacea are regularly recorded in the European Atlantic Ocean (Brongersma 1972, Godley et al. in press) and in the Mediterranean Sea (Margaratoulis 1986, Taskavak et al. 1998).

After hatching, marine turtles undergo a little known pelagic phase, during which all species are thought to be omnivorous, feeding upon planktonic items for a number of years. Following this, it is hypothesised that individuals migrate to a juvenile developmental habitat, usually neritic (see Musick \& Limpus 1997 for review). Studies suggest that, in general, juvenile turtles remain there until adulthood, at which time they begin seasonal migrations between foraging areas and seasonal breeding grounds which may be undertaken every few years.

In a recent review of marine turtle feeding ecology, Bjorndal (1997) suggested that although green turtles 
are largely herbivorous during most life history stages, in the pelagic juvenile phase this species is likely to be omnivorous, with a strong tendency towards carnivory. There are, however, no published records of the diet of green turtles in the Mediterranean, and there is a paucity of dietary information regarding pelagic juvenile stages of all turtle species world-wide. For postpelagic juvenile and adult loggerhead turtles, a review of prey items taken in other regions found the diet to be dominated by benthic molluscs, crustaceans and coelenterates (Dodd 1988). The small number of conventional dietary studies undertaken in the Mediterranean have reported similar findings (Laurent \& Lescure 1992, 1994, Godley et al. 1997), indicating that individuals stranded dead or incidentally caught in fishing gear had been feeding largely on benthic molluscs and crustacea (Tunisia and Cyprus), but also upon echinoderms and other items in relatively small proportions (Tunisia). The leatherback turtle is thought to be the most pelagic of all sea turtle species, feeding upon jellyfish, salps and other gelatinous organisms (Biorndal 1997).

Without direct observation, it is virtually impossible to obtain meaningful dietary information from live, free-living turtles. Animals found dead provide the only realistic opportunity to gather dietary data. However, data obtained from analysis of gut contents from dead turtles have several associated limitations (Duffy \& Jackson 1986): ingested food items need to be present and identifiable at the time of examination; there is a likelihood of overestimating the proportion of relatively non-digestible, hard-bodied items; and such data only yield a relatively proximate indication of dietary choice.

Stable isotope analysis of assimilated proteins overcomes some of these problems. The technique utilises the fact that the ratios of stable isotopes in proteins of consumers tend to reflect those in their diets in a predictable way (DeNiro \& Epstein 1978, 1981, Peterson \& Fry 1987). For nitrogen, the ratio of ${ }^{15} \mathrm{~N}$ to ${ }^{14} \mathrm{~N}$ (conventionally expressed as $\delta^{15} \mathrm{~N}$ ) exhibits a stepwise enrichment at each trophic level (Minagawa \& Wada 1984, Schoeninger \& DeNiro 1984, Hobson et al. 1994), which is thought to be due to differential excretion of the lighter isotope (Peterson \& Fry 1987). Hence, biota feeding at relatively high trophic positions will exhibit correspondingly high $\delta^{15} \mathrm{~N}$ values.

In the case of carbon, the ratio of ${ }^{13} \mathrm{C}$ to ${ }^{12} \mathrm{C}$ (conventionally expressed as $\delta^{13} \mathrm{C}$ ) also shows a tendency to increase with trophic level, but to a lesser degree than $\delta^{15} \mathrm{~N}$ (McConnaughy \& McRoy 1979, Chisholm et al. 1982, Rau et al. 1983, Fry \& Sherr 1984, Hobson \& Welch 1992). However, the $\delta^{13} \mathrm{C}$ value can provide information about the source of carbon entering the food chain, for example distinguishing between marime and freshwater systems (Hobson 1987, Mizutani et al 1990, Hobson \& Sealy 1991). Furthermore, the timescale over which dietary information is represented by a given isotope signature varies with tissue type and depends largely upon metabolic turnover (Tieszen et al. 1983, Hobson \& Sealy 1991, Hobson \& Clark 1992a, 1993, Hobson 1993). For example, isotope signatures of bone collagen, a protein with a relatively slow turnover, are thought to represent an integration of dietary information over an extended period, possibly approaching the lifetime of the individual (see Stenhouse \& Baxter 1979, Tieszen et al. 1983, Hobson 1987).

The analysis of stable isotopes has been used in a wide range of dietary studies in other marine vertebrates, such as fish (e.g. Harrigan et al. 1989, SholtoDouglas et al. 1991), seabirds (e.g. Hobson 1993, Hobson et al. 1994, Minami et al. 1995, Thompson \& Furness 1995, Thompson et al. 1995, Sydeman et al. 1997) and marine mammals (e.g. Hobson et al. 1995, 1996, Ames et al. 1996, Best \& Schell 1996, Smith et al. 1996). Indeed, attempts have been made to describe inter-species relationships in whole food webs using stable isotope markers (e.g. Fry $19 \hat{9} 8 \hat{8}$, Rau ei al. 1992, Hobson et al. 1995). This study employed stable nitrogen and carbon isotope analysis of collagen extracted from bones, egg derived proteins and carapace scutes to investigate trophic patterns in 4 species of marine turtles. This is the first time that stable isotope analysis has been applied to investigate trophic relationships in this group

\section{MATERIALS AND METHODS}

Sampling. Humeri and epidermal carapace scutes were collected from turtles found dead on the coasts of northern Cyprus and southern Turkey (loggerhead turtles, $n=11$ bone samples; green turtles, $n=38$ bone samples, $n=17$ scutes). At time of collection, medial curved carapace length (CCL) was measured as an index of size (to the nearest $\mathrm{cm}$ ) using a flexible tapemeasure. A small sample of humeri from adult leatherback turtles stranded on the coasts of Scotland $(n=1)$ and Wales $(n=2)$ were obtained for comparative purposes. Nest contents, i.e. whole dead hatchlings, whole embryos in late stages of development (including yolk) and whole eggs which failed to develop, were obtained from nests of both loggerhead turtles ( $n=19$ ) and green turtles ( $\mathrm{n}=20$ ) subsequent to hatching at Alagadi, northern Cyprus. This was carried out according to an established protocol for nest excavation (Broderick \& Godley 1996). Only a single sample was taken from any one nest. For comparative purposes, carbon and nitrogen isotope data were made available from a preliminary study (Moncada et al. 1997) investi- 
gating the isotopic signatures of 'tortoise-shell' from hawksbill turtles Eretmochelys imbricata collected from a wide range of sites including Cuba, Mexico, Solomon Islands, Fiji, Indonesia, The Philippines and Africa $(\mathrm{n}=89)$.

Sample preparation. Bones were cleaned of muscle and associated connective tissue and then oven-dried at $50^{\circ} \mathrm{C}$ to constant mass. They were then coarsely divided using a band saw before being ground to a fine powder using an impactor mill operating at liquid nitrogen temperatures. For large bones, the sample consisted of approximately equal portions of epiphysis and diaphysis, whereas, for turtles less than $35 \mathrm{~cm}$ $\mathrm{CCL}$, both humeri were used. Collagen extraction of bone samples was carried out using a protocol based on that of Chisholm et al. (1983) and used previously in the same laboratory (Thompson \& Furness 1995). Lipids were removed from the collagen extract using a Soxhlet apparatus with refluxing chloroform. Following this, samples were re-dried to remove solvent. Nest contents (minus egg shells) were ground and subjected to lipid extraction as for bone samples. It was assumed that carapace keratin samples would contain negligible amounts of lipid and these were rinsed with distilled water to remove any surface contaminants and then ground.

Stable isotope analysis. All isotopic measurements were determined by continuous flow isotope ratio mass spectrometry (CF-IRMS) using a Finnigan Tracer Matt. Isotope ratios are expressed as $\delta$ values in parts per thousand (\%) according to the following equation:

$$
\delta X=\left(\frac{R_{\text {sample }}}{R_{\text {standard }}}-1\right) \times 1000
$$

where $X$ is ${ }^{15} \mathrm{~N}$ or ${ }^{13} \mathrm{C}$ and $R_{\text {sample }}$ is the corresponding ratio, ${ }^{15} \mathrm{~N} /{ }^{14} \mathrm{~N}$ or ${ }^{13} \mathrm{C} /{ }^{12} \mathrm{C}$. $R_{\text {standard }}$ for ${ }^{13} \mathrm{C}$ is PeeDee Belemnite (PDB) and $R_{\text {standard }}$ for ${ }^{15} \mathrm{~N}$ is atmospheric nitrogen (AIR). All groups of analyses included standard reference materials for routine quality control. All samples were determined in triplicate, with the outlying datum being discarded and the mean value being calculated from the remaining data.

In addition, as a quantitative test of analytical consistency, a random selection of samples $(n=23)$ were determined in triplicate on 2 separate occasions. On each occasion, the outlying datum was discarded and the mean calculated of the remaining 2 values. These data were then subjected to repeatability analysis (Harper 1994). This involved calculating the intra-class correlation coefficient which was calculated from the variance components derived from a 1-way analysis of variance (ANOVA) as:

$$
r=\frac{S_{\mathrm{a}}^{2}}{S^{2}+S_{\mathrm{a}}^{2}}
$$

where $S_{\mathrm{a}}^{2}$ is the among-groups variance component and $S^{2}$ is the within-group variance component. Results of both isotope signatures were found to be very highly repeatable $\left(r=0.94\right.$ for $\delta^{13} \mathrm{C} ; \mathrm{r}=0.96$ for $\left.\delta^{15} \mathrm{~N}\right)$, showing the analytical protocol to produce highly consistent values for individual samples. All statistical tests were 2-tailed.

\section{RESULTS}

\section{Size class distribution of individuals sampled}

The size class distributions of the 3 species were markedly different (loggerhead turtles: mean $\mathrm{CCL}=$ $62.1 \mathrm{~cm}, \mathrm{SD}=15.48$, range $=23$ to $79 \mathrm{~cm}, \mathrm{n}=11 ;$ green turtles: mean CCL $=41.2 \mathrm{~cm}, \mathrm{SD}=18.5$, range $=21$ to $98 \mathrm{~cm}, \mathrm{n}=38$; leatherback turtles: mean $\mathrm{CCL}=182 \mathrm{~cm}$, $\mathrm{SD}=3.5$, range $=180$ to $186 \mathrm{~cm}, \mathrm{n}=3$ ). Small sample size precluded leatherback turtles from statistical analyses. However, the difference between mean CCL of green turtles and loggerhead turtles was statistically significant $\left(t_{47}=3.71, \mathrm{p}=0.0016\right)$.

\section{Isotope signatures of bone collagen}

Isotope signatures of bone collagen in the 3 species are presented in Table 1 The mean $\delta^{15} \mathrm{~N}$ signature for loggerhead turtles (20.0\%; Table 1) was significantly higher than that for green turtles $\left(9.9 \%\right.$; Table $1 ; t_{47}=$ $8.89, \mathrm{p}<0.0001$ ). There was, however, no significant difference in the mean $\delta^{13} \mathrm{C}$ values of these 2 species $\left(t_{47}=0.60, p=0.55 ;\right.$ loggerhead turtles, $-14.6 \%$, green turtles, $-15.4 \%$; Table 1$)$. Although the range in $\delta^{1.3} \mathrm{C}$ values in loggerhead turtles was typically marine $(-17.5$ to $-11.4 \%$; Table 1$)$, that of green turtles was much wider $(-25.7$ to $-7.7 \%$; Table 1$)$

Leatherback turtles had a mean $\delta^{15} \mathrm{~N}$ signature (14.1\%; Table 1) intermediate to and a mean $\delta^{13} \mathrm{C}$ signature (-19.0\%; Table 1) lower than the other 2 species. Fig. 1 illustrates the combined carbon and nitrogen signatures in extracted bone collagen from green and loggerhead turtles compared with those from all other tissues analysed in this study.

For loggerhead turtles there was a significant positive correlation between size (CCL) and both $\delta^{15} \mathrm{~N}$ (Fig. $\left.2 ; \mathrm{R}_{10}=0.74, \mathrm{p}=0.008\right)$ and $\delta^{13} \mathrm{C}$ value $\left(\mathrm{R}_{10}=0.59\right.$. $p=0.03$ ). However, similar correlations were not found for green turtles for either $\delta^{15} \mathrm{~N}$ [Fig. $2 ; \mathrm{R}_{37}=0.01, \mathrm{p}=$ 0.89 , not significant (ns)] or $\delta^{13} \mathrm{C}\left(\mathrm{R}_{37}=0.27, \mathrm{p}=0.124\right.$, $\mathrm{ns})$. In addition, although a significant correlation was found between $\delta^{15} \mathrm{~N}$ and $\delta^{13} \mathrm{C}$ in loggerhead turtle collagen samples $\left(\mathrm{R}_{10}=0.80, \mathrm{p}=0.003\right)$, this was not the case for collagen extracted from green turtle bones $\left(\mathrm{R}_{37}=0.20, \mathrm{p}=0.214\right.$, ns $)$. 
Table 1. Descriptive statistics of both $\delta^{15} \mathrm{~N}$ and $\delta^{13} \mathrm{C}$ for all samples in the study

\begin{tabular}{|c|c|c|c|c|c|}
\hline \multirow[t]{2}{*}{ Sample type } & \multirow[t]{2}{*}{$\mathrm{n}$} & \multicolumn{2}{|c|}{$\delta^{15} \mathrm{~N}(\%)$} & \multicolumn{2}{|c|}{$\delta^{13} \mathrm{C}(\%)$} \\
\hline & & Mean (SD) & Range & Mean (SD) & Range \\
\hline \multicolumn{6}{|l|}{ Bone collagen } \\
\hline Loggerhead turtles & 11 & $20.0(3.53)$ & 13.1 to 26.4 & $-14.6(1.84)$ & -17.5 to -11.4 \\
\hline Green turtles & 38 & $9.4(1.84)$ & 3.71017 .3 & $-15.4(4.31\}$ & -25.7 to -7.7 \\
\hline Leatherback turtles & 3 & $14.1(0.52)$ & 13.6 to 14.6 & $-19.0(5.43)$ & -25.3 to -15.4 \\
\hline \multicolumn{6}{|l|}{ Nest contents } \\
\hline \multicolumn{6}{|l|}{ Loggerhead turtles } \\
\hline Overall 'egg derived protein' & 19 & $7.6(1.65)$ & 3.3 to 10.2 & $-16.6(1.92)$ & -20.5 to -13.6 \\
\hline Hatchlings & 8 & $7.8(1.76)$ & 5.6 to 10.2 & $-17.2(1.85)$ & -20.5 to -14.6 \\
\hline Embryos & 8 & $7.9(1.01)$ & 6.6 to 9.3 & $-16.4(2.18)$ & -19.6 to -13.6 \\
\hline Eggs & 3 & $6.6(2.85)$ & 3.3 to 8.4 & $-15.4(1.24)$ & -16.2 to -14.0 \\
\hline \multicolumn{6}{|l|}{ Green turtles } \\
\hline Overall 'egg derived protein' & 20 & $5.1(1.28)$ & 3.3 to 7.5 & $-11.7(1.91)$ & -15.3 to -8.5 \\
\hline Hatchlings & 7 & $4.4(0.87)$ & 3.4 to 5.3 & $-10.8(1.80)$ & -13.1 to -8.5 \\
\hline Embryos & 7 & $5.5(1.44)$ & 3.4 to 7.5 & $-11.7(1.54)$ & -14.8 to -10.3 \\
\hline Eggs & 6 & $5.4(1.38)$ & 3.3 to 7.1 & $-12.7(2.21)$ & -15.3 to -10.1 \\
\hline \multicolumn{6}{|l|}{ Carapace scute } \\
\hline Green turtles & 17 & $5.2(1.79)$ & 2.2 to 8.8 & $-14.8(3.43)$ & -22.3 to -10.5 \\
\hline Hawksbill turtles & 89 & $7.2(2.24)$ & 2.7 to 12.3 & $-14.4(1.95)$ & -1.9 .5 to -8.8 \\
\hline
\end{tabular}

\section{Trophic relationships using nest contents}

Summary statistics of the isotope signatures of all nest contents are presented in Table 1. There were insufficient data regarding undeveloped eggs of loggerhead turtles $(n=3)$ to statistically test for any differences between the levels in these samples and those of conspecific hatchlings or embryos. There was, however, no significant difference between loggerhead turtle hatchlings (mean $\delta^{15} \mathrm{~N}=7.8 \%$; mean $\delta^{13} \mathrm{C}=$ $-17.2 \%$; Table 1) and loggerhead turtle embryos (mean $\delta^{15} \mathrm{~N}=7.9 \%$; mean $\delta^{13} \mathrm{C}=-16.4 \%$; Table 1 ) in either $\delta^{15} \mathrm{~N}$ signature $\left(t_{14}=0.72, \mathrm{p}=0.48, \mathrm{~ns}\right)$ or $\delta^{13} \mathrm{C}$

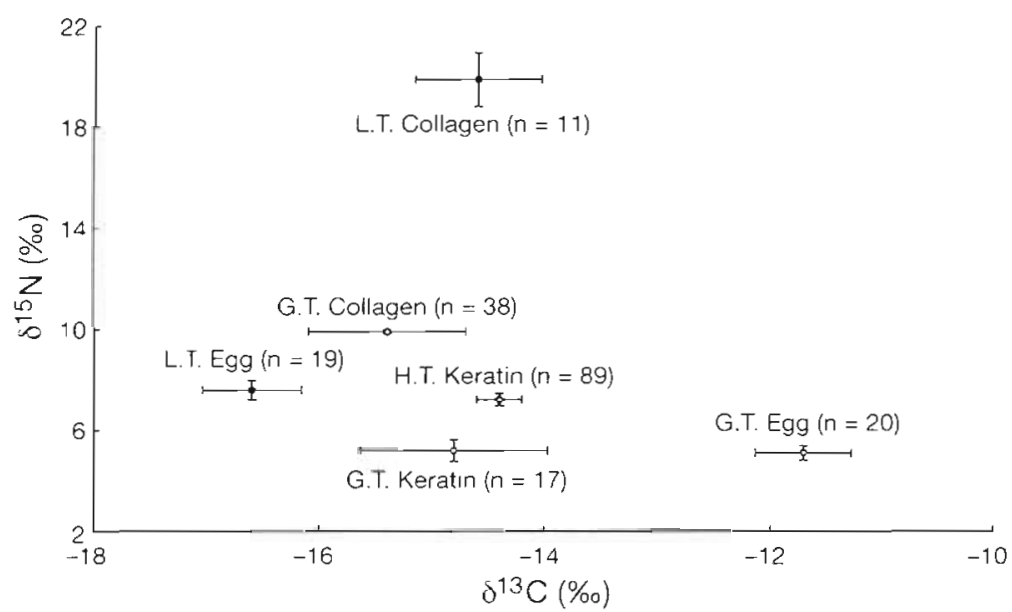

Fig. 1. Comparison of isotopic signatures (mean $\pm \mathrm{SE}$ ) in the bone collagen (Collagen) and egg protein (Egg) of green (G.T.) and loggerhead turtles (L.T.) with those from carapace scute keratin (Keratin) from green and hawksbill turtles (H.T.) signature $\left(t_{14}=0.1 \overline{8}, p=0.86, n s j\right.$. Sinitiarly, there wore no significant differences among the 3 categories of nest contents from green turtle samples for $\delta^{15} \mathrm{~N}$ (ANOVA, $\left.F_{2,17}=1.5, \mathrm{p}=0.25, \mathrm{~ns}\right)$ or $\delta^{13} \mathrm{C}$ (ANOVA, $\left.F_{2,17}=1.6, \mathrm{p}=0.224, \mathrm{~ns}\right)$.

Since no within-species differences were found, it was assumed that, from each species, all samples of nest contents could be grouped as a single category, 'egg derived protein', for the purpose of inter-specific comparisons (Table 1). There was a marked difference between the isotope signatures of egg derived protein and conspecific bone collagen. This was true both for green turtles (see next section) and loggerhead turtles $\left(\delta^{15} \mathrm{~N}: t_{28}=10.92, \mathrm{p}<0.0001 ; \delta^{13} \mathrm{C}: t_{28}=\right.$ 2.77, $\mathrm{p}=0.01$ ).

The mean $\delta^{15} \mathrm{~N}$ value of loggerhead turtle egg proteins (7.6\%; Table 1) was significantly higher than that of green turtles $\left(5.1 \%\right.$; Table $1 ; t_{37}=5.36, \mathrm{p}<$ $0.0001)$. In addition, unlike results for bone collagen (see above), there was a significant difference in $\delta^{13} \mathrm{C}$ between the 2 species $\left(t_{47}=7.95, p<0.0001\right)$, with green turtle egg derived proteins (mean $\delta^{13} \mathrm{C}=-11.7 \%$; Table 1 ) exhibiting higher levels than those in loggerhead turtles (mean $\delta^{13} \mathrm{C}=-16.6 \%$; Table 1). Fig. 1 illustrates the $\delta^{13} \mathrm{C}$ and $\delta^{15} \mathrm{~N}$ signatures of nest contents from green and loggerhead turtles, compared with conspecific collagen signatures and the levels in carapace scutes of both green and hawksbill turtles. 


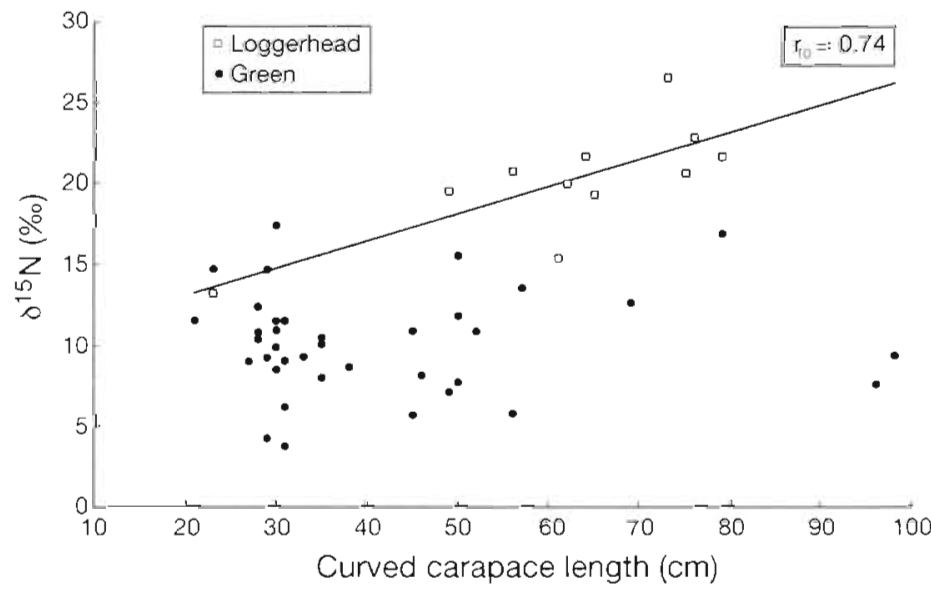

Fig. 2. $\delta^{15} \mathrm{~N}$ in bone collagen vs curved carapace length in both green and loggerhead turtles. Coefficient of correlation $\left(\mathrm{r}_{10}\right)$ is shown for loggerhead turtles
2 to 3 trophic levels above green turtles. Although based on a small sample size, leatherback turtles appear to feed at an intermediate trophic level. These isotopic data generally confirm available dietary information collected conventionally regarding these species. Green turtles are thought to be largely herbivorous at most life history stages, leatherback turtles specialise on gelatinous organisms, whilst loggerhead turtles are thought to be essentially carnivorous, feeding on molluscs and crustacea (Bjorndal 1997).

Stable isotope analysis has been suggested as a potential means of identifying the origin of tortoise-shell (Moncada et al. 1997), so aiding policing of legitimate trade if limited international trade were ever permitted. Given the substantial overlap in both isotope signatures it is unlikely that green turtle carapace scutes could be differentiated from those of hawksbill

\section{Isotopic composition of epidermal carapace scutes}

Whereas the mean $\delta^{15} \mathrm{~N}$ of carapace scutes (green turtles 5.2\%o, hawksbill turtles $7.2 \%$; Table 1) was significantly different between species $\left(t_{104}=3.4, \mathrm{p}=\right.$ 0.001 ), the mean $\delta^{13} \mathrm{C}$ signatures (green turtles $-14.8 \%$ hawksbill turtles $-14.3 \%$; Table 1$)$ were not $\left(t_{104}=0.78\right.$, $\mathrm{p}=0.44$ ). Among green turtle samples, the $\delta^{15} \mathrm{~N}$ signatuires of the 3 different protein extracts were significantly different (ANOVA, $F_{2,91}=33.06, p<0.0001$ ), with the $\delta^{15} \mathrm{~N}$ of bone collagen higher than that for either egg protein or carapace scutes (modified Tukey test for uneven samples; Zar 1984). The $\delta^{13} \mathrm{C}$ signatures of the 3 green turtle protein extracts were also significantly different (ANOVA, $F_{2,91}=7.09, p=0.002$ ), with the $\delta^{13} \mathrm{C}$ of egg protein significantly higher than that for either bone collagen or carapace scutes (modified Tukey test for uneven samples; Zar 1984). There were no correlations between size (CCL) and $\delta^{15} \mathrm{~N}\left(\mathrm{R}_{16}=\right.$ $0.17, p=0.51$, ns $)$ or $\delta^{13} \mathrm{C}\left(\mathrm{R}_{16}=0.30, \mathrm{p}=0.242\right.$, ns $)$ in the keratin from carapace scutes of green turtles.

\section{DISCUSSION}

This is the first study to utilise the power of stable isotope analysis to elucidate trophic relationships in marine turtles. The isotope data for bone collagen show clear species differences. Based on $\delta^{13} \mathrm{~N}$ signatures, loggerhead turtles feed at the highest trophic level of the species studied here, which, given an average 3 to $4 \%$ enrichment for each trophic step (Minagawa \& Wada 1984, Schoeninger \& DeNiro 1984 Hobson \& Welch 1992, Hobson 1993, Hobson et al. 1994), would suggest that they are feeding on average turtles using a simple 2 isotope technique. To differentiate among populations of the same turtle species, it is likely that it would be necessary to use isotopic analysis of additional elements and/or incorporate the analysis of trace elements into a multivariate approach, as undertaken previously for African elephant Loxodonta africana ivory (Vogel et al. 1990).

The $\delta^{15} \mathrm{~N}$ values for many loggerhead turtles in this study are higher than might be expected, given published values for most molluscs and crustacea which have been found to range from approximately 7 to 16\% (McConnaughey \& McRoy 1979, Fry 1988, Hobson 1993). There are no published values for fractionation factors between nitrogen isotopic signatures of prey and those in tissues of marine turtles. These have, however, been determined in other taxa. In captive ring-billed gulls Larus delawarensis, Hobson \& Clark (1992b) reported a diet-collagen fractionation factor of $+3.1 \%$, and in a study of captive seals, Hobson et al. (1996) found that no diet-tissue fractionation factor exceeded $+3.1 \%$ for nitrogen. Bearhop et al. (1998) found diet-feather keratin fractionation factors of between +3.6 and $+4.9 \%$ for 3 species of piscivorous bird.

It is noteworthy that the mean $\delta^{15} \mathrm{~N}$ for green turtles is higher than would be expected for an obligate herbivore. The range of $\delta^{15} \mathrm{~N}$ values in a selection of marine plants from the Mediterranean was 1.1 to $4.1 \%$ (Jennings et al. 1997) If the primary food source for green turtles was plant matter, and the diet-tissue fractionation factor was between 3 and $4 \%$, this would lead to a likely range in collagen $\delta^{15} \mathrm{~N}$ signature in the region of 4 to $8 \%$. The mean $\delta^{15} \mathrm{~N}$ value reported here $19.9 \%$; Table 1) would imply that green turtles do not feed solely on marine plants, but also consume animal 
tissue enriched in ${ }^{15} \mathrm{~N}$. This could be as an incidental part of relatively unselective herbivory. It is likely that a substantial number of animal items such as fish eggs, molluscs and crustacea will be consumed with plant matter, and, although green turtles are thought to be largely herbivorous, numerous anecdotal accounts exist of animal items being found in gut contents in this species (reviewed by Bjorndal 1997). However, green turtles may selectively feed on animal tissues such as fish eggs and invertebrates, as our isotope data suggest that animal matter may provide a substantial part of the protein in the diet of this species.

Carbon isotope signatures were found to be very similar in bone collagen of both Mediterranean breeding species (Table 1). However, the mean $\delta^{13} \mathrm{C}$ signatures in green and loggerhead turtles were elevated compared to that of leatherback turtles (Table 1). From inter-species comparisons of isotope signatures in seabirds, pelagically feeding species tend to have more negative $\delta^{13} \mathrm{C}$ signatures than inshore or benthically feeding species (Hobson et al. 1994). The depleted $\delta^{13} \mathrm{C}$ values reported here for leatherback turtles would be consistent with the highly pelagic nature of that species, whilst the neritic feeding preferences of both loggerhead and green turtles could explain the relatively elevated $\delta^{13} \mathrm{C}$ values found in these species (Table 1).

The relatively high variance of $\delta^{13} \mathrm{C}$ values of collagen samples from green turtles (range: -25.7 to $-7.7 \%$; Table 1) reported here is of particular interest. It implies that some green turtles may have fed primarily in a pelagic environment (relatively low $\delta^{13} \mathrm{C}$ values, see above), whilst others have fed on a relatively ${ }^{13} \mathrm{C}$ rich food source, sea grass being the obvious candidate (Boon \& Bunn 1994, Bunn et al. 1995, Hemminga \& Mateo 1996).

Paradoxically, although the mean size of nesting loggerhead turtles is less than that of green turtles in the eastern Mediterranean (Broderick \& Godley 1996), the individuals stranded and subsequently sampled for this study showed the converse trend. This is a pattern which has previously been noted in stranded turtles in the region (Baran \& Kasparek 1989). It is thought to be due to small juvenile loggerhead turtles not being present in the eastern Mediterranean, but occupying a relatively remote and, as yet, undiscovered developmental habitat. Notwithstanding, due to the comprehensive sampling regime undertaken, samples were obtained from small juvenile through to adult size ranges for both species.

As loggerhead turtles increase in size, they appear to feed at progressively higher trophic levels (Fig. 2). No size-related relationships were found in the isotope signatures of green turtle bone collagen (see 'Results' and Fig. 2). This may suggest that bone collagen, at least in this species and possibly in marine turtles generally, may not represent dietary information integrated over extended periods, approaching the lifetime of the individual, as is thought the case in other groups (see Stenhouse \& Baxter 1979, Tieszen et al. 1983, Hobson 1987). If isotopic values in turtle bone collagen approached a lifetime integration of dietary information, small green turtles would be expected to show higher $\delta^{15} \mathrm{~N}$ signatures and lower $\delta^{13} \mathrm{C}$ signatures due to omnivorous feeding whilst in the pelagic juvenile stage. That this may indeed be the case in marine turtles is further supported by the following: (1) marine turtles are slow to mature, with reported estimates ranging from at least 9 to $14 \mathrm{yr}$ in leatherback turtles, 19 to $27 \mathrm{yr}$ in green turtles, and in excess of $20 \mathrm{yr}$ for loggerhead turtles (Zug \& Parham 1996); (2) being reptiles, turtles are likely to experience skeletal growth throughout this maturation period and possibly beyond; and (3) this skeletal growth is likely to involve constant remodelling and metabolism of bone elements. It is unlikely, therefore, that bone collagen will represent more than medium-range dietary preferences of, say, severai years. iñ addition, no size-related relationships with isotope signatures of carapace scute keratin were found. It is likely that reasons (1) and (2) above compounded by physical wear on the external surface of scutes will mean that this protein is also only indicative of medium-term dietary influences.

The use of isotopic analysis of egg components to trace avian diets has been suggested previously (Hobson 1995). It appears that there are no differences between the isotope signatures of undeveloped eggs, dead-in-shell embryos or dead hatchlings (see 'Results' and Table 1) and that all may be considered as samples indicative of maternally derived 'egg proteins'. This being the case, dead hatchlings and embryos would make ideal units for future comparisons with other species and locations as they can be sampled noninvasively after the completion of the hatching process.

The fractionation of different isotopes between diet and consumer tissues varies between different tissues within a species (Mizutani et al. 1990, Hobson \& Clark $1992 \mathrm{a}$, b). It is not known why egg protein $\delta^{15} \mathrm{~N}$ was markedly lower than that of bone collagen in both Mediterranean species (Table 1). Diet-tissue fractionation factors are not known for marine turtles and would require controlled feeding trials in order to be determined. The between-species differences in $\delta^{15} \mathrm{~N}$ were, however, consistent with the general difference in feeding preferences already discussed. A significant difference existed in egg derived protein $\delta^{13} \mathrm{C}$ values between loggerhead and green turtles (Table 1) which was not found in the analysis of collagen. This may be complicated by the fact that collagen samples were collected from a wide range of size classes of both 
species from small juveniles to full grown aduits. Egg proteins are solely of adult origin, where the difference in feeding between these species is likely to be most divergent and any inter-specific dietary-related differences in isotope signatures are more likely to be elucidated. The most enriched $\delta^{13} \mathrm{C}$ signature of all tissues analysed was that of the green turtle eggs; this would be consistent of a diet dominated by vegetation such as seagrass (Boon \& Bunn 1994, Bunn et al. 1995, Hemminga \& Mateo 1996, Jennings et al. 1997). These marked inter-tissue differences from the same species highlight the fact that the most rigorous inter-specific comparisons of dietary intake of consumers through stable isotope analysis should, wherever possible, involve the same tissue type.

Acknowledgements. Many thanks to H. Koike, Kyushu University, for giving access to data regarding isotopic ratios in hawksbill tortoise-shell and the many individuals and organisations who have helped by collecting information regarding strandings, especially: members of GUTCE 1992-1996; Institute of Marine Sciences, Middle East Technical University, Turkey; Marine Environmental Monitoring, Wales; and SAC Wildlife Unit, Scotland. Isotope analyses were carried out by Julie Dougans within the Life Sciences Community Stable Isotope Facility, which is funded by a consortium of Scottish Universities and the Natural Environment Research Council. We also acknowledge the assistance of S. Bearhop, A. C. Broderick, P. Catry, and S. E. Solomon, all University of Glasgow, and A. E. Fallick, SURRC. B.J.G. was funded under a Iniversity of Glasgow postgraduate scholarship, with field costs being partly met by the Carnegie Trust for the Universities of Scotland. In addition, the manuscript benefited from the constructive criticism of 4 anonymous referees.

\section{LITERATURE CITED}

Ames AL, van Vleet ES, Sacket WM (1996) The use of stable carbon isotope analysis for determining the dietary habits of the Florida manatee (Trichechus manatus latirostis). Mar Mamm Sci 12(4):555-563

Baran I, Kasparek M (1989) On the whereabouts of immature sea turtles (Caretta caretta and Chelonia mydas) in the eastern Mediterranean. Zool Middle East 3:31-36

Bearhop S, Thompson DR, Waldron S, Russell IC, Alexander A, Furness RW (1998) Stable isotopes indicate the extent of freshwater feeding by Cormorants (Phalocrocorax carbo) from inland fisheries in England. In: Conference proceedings: applications of stable isotope techniques to ecological studies, Saskatoon, Saskatchewan, April 20-22, 1998. University of Saskatchewan, Saskatoon

Best PB, Schell DM (1996) Stable isotopes in southern right whale (Eubalaena australis) baleen as indicators of seasonal movements, feeding and growth. Mar Biol 124: 483-494

Bjorndal KA (1997) Foraging ecology and nutrition of sea turtles. In: Lutz PL, Musick JA (eds) The biology of sea turtles. CRC Press, Boca Raton, FL, p 199-231

Boon PI, Bunn SE (1994) Variations in stable isotope composition of aquatic plants and their implications for food web analysis. Aquat Bot 48:99-10

Broderick AC, Godley BJ (1996) Population and nesting ecology of the green turtle (Chelonia mydas) and the logger- head turtle (Caretta caretta) in northern Cyprus. Zool Middle East 13:27-46

Brongersma LD (1972) European A.tlantic turtles. Zool Verhand 121 Rijksmuseum van Natuurlijke Historie, Leiden

Bunn SE, Lonergan NR, Kempster MA (1995) Effects of acid washing on stable isotope ratios of $\mathrm{C}$ and $\mathrm{N}$ in penaeid shrimp and sea grass: implications for food web studies using multiple stable isotopes. Limnol Oceanogr 40(3): $622-625$

Chisholm BS, Nelson DE, Hobson KA, Schwarcz HP, Knyf M (1983) Carbon isotope measurement techniques for bone collagen: notes for the archaeologist. J Archaeol Sci 10: $355-360$

Chisholm BS, Nelson DE, Schwarcz HP (1982) Stable-carbon isotope ratios as a measure of marine versus terrestrial protein in ancient diets. Science 216:1131-1132

DeNiro MJ, Epstein S (1978) Influence of diet on the distribution of carbon isotopes in animals. Geochim Cosmochim Acta 42:495-506

DeNiro MJ, Epstein S (1981) Influence of diet on the distribution of nitrogen isotopes in animals. Geochim Cosmochim Acta 45:341-351

Dodd CK (1988) Synopsis of the biological data on the loggerhead sea turtle Caretta caretta (Linnaeus 1758). Biol Rep 88(14), FAO Synopsis NMFS-149, NMFS, Washington, DC

Duffy DC, Jackson $\mathrm{S}$ (1986) Diet studies in seabirds: a review of methods. Colon Waterbirds 19:1-17

Fry B (1988) Food web structure in George's Bank from stable C, $N$, and $\mathrm{S}$ isotopic compositions. Limnol Oceanogr 33(5): $1182-1190$

Fry B, Sherr $\mathrm{E}(1984) \delta^{13} \mathrm{C}$ measurements as indicators of carbon flow in marine and freshwater systems. Contrib Mar Sci $27: 13-47$

Godley BJ. Gaywond M.I, Law RI, McCarthy CJ, McKenzis C, Patterson IAP, Penrose RS, Reid RJ, Ross HM (in press) Patterns of marine turtle mortality in British waters (1992-1996) with reference to tissue contaminant levels. J Mar Biol Assoc UK

Godley BJ, Smith SM, Clark PF, Taylor JT (1997) Molluscan and crustacean items in the diet of the loggerhead turtle, Caretta caretta (Linnaeus 1758) [Testudines: Chelonidae) in the eastern Mediterranean. J Mollusc Stud 63:476-478

Groombridge B (1990) Marine turtles in the Mediterranean: distribution, population status, conservation. Nature and Environment Series No. 48, Council of Europe, Strasbourg

Harper DCG (1994) Some comments on the repeatability of measurements. Ringing Migr 15:84-90

Harrigan P, Zieman JC, Macko SA (1989) The base of nutritional support for the gray snapper Lutjanus griseus: an evaluation based on combined stomach content and stable isotope analysis. Bull Mar Sci 44:66-77

Hemminga MA, Mateo MA (1996) Stable carbon isotopes in seagrasses-varlability in ratios and use in ecological studies. Mar Ecol Prog Ser 140:285-298

Hobson KA (1987) Use of stable-carbon isotope analysis to estimate marme and terrestrial content in gull diets. Can J Zool 65:1210-1213

Hobson KA (1993) Trophic relationships among high Arctic seabirds: insights from tissue-dependent stable isotope models. Mar Ecol Prog Ser 95:7-18

Hobson KA (1995) Reconstructing avian diets using stable carbon and nitrogen isotope analysis of egg components: patterns of isotopic fractionation and turnover. Condor 97:752-762

Hobson KA, Ambrose WG Jr, Renaud PE (1995) Sources of primary production, benthic-pelagic coupling, and trophic 
relationships within the Northeast Water Polynya: insights from $\delta^{13} \mathrm{C}$ and $\delta^{15} \mathrm{~N}$ analysis. Mar Ecol Prog Ser 128:1-10

Hobson KA, Clark RG (1992a) Assessing avian diets using stable isotopes I: turnover of $\delta^{13} \mathrm{C}$ in tissues. Condor 94: $181-188$

Hobson KA, Clark RG (1992b) Assessing avian diets using stable isotopes II: factors influencing diet-tissue fractionation. Condor 94:189-197

Hobson KA, Clark RG (1993) Turnover of ${ }^{13} \mathrm{C}$ in cellular and plasma fractions of blood: implications for non-destructive sampling in avian dietary studies. Auk 110:638-641

Hobson KA, Piatt JF, Pitocechelli J (1994) Using stable isotopes to determine seabird trophic relationships. J Anim Ecol 63:786-798

Hobson KA, Schell DM, Renouf D, Noseworthy E (1996) Stable carbon and nitrogen isotopic fractionation between diet and tissues of captive seals: implications for dietary reconstruction involving marine mammals. Can J Fish Aquat Sci 53:528-533

Hobson KA, Sealy SG (1991) Marine protein contributions to the diet of northern sawwhet owls on the Queen Charlotte ssicnds, British Colombia: a stable isotope approach. Auk 108:437-440

Hobson KA, Welch HE (1992) Determination of trophic relationships within a high Arctic marne food web using $\delta^{13} \mathrm{C}$ and $\delta^{15} \mathrm{~N}$ analysis. Mar Ecol Prog Ser 84:9-18

Jennings $S$, Roñones $O$, Morales-Nin $B$, Polunin NVC Moranta J, Coll J (1997) Spatial variation in the ${ }^{15} \mathrm{~N}$ and ${ }^{13} \mathrm{C}$ stable isotope composition of plants, invertebrates and fishes on Mediterranean reefs: implications for the study of trophic pathways. Mar Ecol Prog Ser 146:109-116

Laurent L, Lescure $J$ (1992) The status of marine turtles in the Gulf of Gabès (South Tunisia). Proc 6th Ord Gen Meet SEH, Budapest 1991:293-295

Laurent L, Lescure J (1994) L'hivernage des tortues caounes Caretta caretta (L) dans le sud Tunisien. Rev Ecol Terre Vie 49:63-86

Margaratoulis D (1986) Captures and strandings of the leatherback sea turtles, Dermochelys conacea, in Greece (1982-1984). J Herpetol 20(3):471-474

McConnaughy T, McRoy CP (1979) Food-web structure and the fractionation of carbon isotopes in the Bering Sea. Mar Biol 53:257-262

Minagawa M, Wada E (1984) Stepwise enrichment of ${ }^{15} \mathrm{~N}$ along food chains: further evidence and the relation between $\delta^{15} \mathrm{~N}$ and animal age. Geochim Cosmochim Acta 48:1135-1140

Minami H, Minagawa M, Ogi H (1995) Changes in stable carbon and nitrogen isotope ratios in sooty and short-tailed shearwaters during their northbound migration. Condor 97:565-574

Mizutani H, Fukuda M, Kabaya Y, Wada E (1990) Carbon isotope ration of feathers reveals feeding behaviour of cormorants. Auk 107:400-403

Moncada FG, Koike H, Espinosa G, Manolis SC, Perez C, Nodarse GA, Tanabe S, Sakai H, Webb GJW, Carrillo EC Diaz R, Tsubouchi T (1997) Annex 8: movement and population integrity. In: An annotated transfer of the

Editorial responsibility: Otto Kinne (Editor), Oldendorf/Luhe, Germany
Cuban population of hawksbill turtles (Eretomochelys imbricata) from CITES appendix I to II, CITES. Lausanne, p 47-57

Musick JA, Limpus CJ (1997) Habitat utilisation and migration of juvenile sea turtles. In: Lutz PL, Musıck JA (eds) The biology of sea turtles. CRC Press, Boca Raton, FL, p $137-163$

Peterson BJ, Fry B (1987) Stable isotopes in ecosystem studies. Annu Rev Ecol Syst 18:293-320

Rau GR, Ainley DG, Bengston JL, Torres JJ, Hopkins TL (1992) ${ }^{15} \mathrm{~N} /{ }^{14} \mathrm{~N}$ and ${ }^{13} \mathrm{C}^{12} \mathrm{C}$ in Weddell Sea birds, seals and fish. implications for diet and trophic structure. Mar Ecol Prog Ser 84:1-8

Rau GR, Mearns AJ, Young DR, Olson RJ, Schafer HA, Kaplan IR (1983) Animal ${ }^{13} \mathrm{C}^{12} \mathrm{C}$ correlates with trophic level in pelagic food webs. Ecology 64:1314-1318

Schoeninger M.J. DeNiro MJ (1984) Nitrogen and. carbon isotopic composition of bone collagen from marine and terrestrial animals. Geochim Cosmochim Acta 48:625-639

Sholto-Douglas AD, Field JG, James AG, van der Merwe NI (1991) ${ }^{13} \mathrm{C} /{ }^{12} \mathrm{C}$ and ${ }^{15} \mathrm{~N} /{ }^{14} \mathrm{~N}$ isotope ratios in the Southern Renguela Ecosystem: indicators of food web relationships among different size-classes of plankton and pelagic fish; differences between fish muscle and bone collagen tissues. Mar Ecol Prog Ser 78:23-31.

Smith RJ, Hobson KA, Koopman HN, Lavigne DM (1996) Distinguishing between populations of freshwater and saltwater harbour seals (Phoca vitalina) using stable isotope ratios and fatty acid profiles. Can J Fish Aquat Sci 53(2): $272-279$

Stenhouse MJ, Baxter MS (1979) The uptake of ${ }^{14} \mathrm{C}$ in humans. In: Berger R, Suess $H$ (eds) Radiocarbon dating. Univ California Press, Berkeley, p 324-341

Sydeman WJ, Hobson KA, Pyle P, MCLaren EB (1997) Trophic relationships among seabirds in central Calıfornia: combined stable isotope and conventional dietary approach. Condor 99:327-336

Taskavak E, Boulon RH Jr, Atataur MK (1998) A Turkish leatherback stranding. Mar Turt News 80:13

Thompson DR, Furness RW (1995) Stable-isotope ratios of carbon and nitrogen in feathers indicate seasonal dietary shifts in northern fulmars. Auk 112:493-498

Thompson DR, Furness RW, Lewis SA (1995) Diets and longterm changes $\delta^{15} \mathrm{~N}$ and $\delta^{13} \mathrm{C}$ values in northern fulmars Fulmarus glacialis from two northeast Atlantic colones. Mar Ecol Prog Ser 125:3-11

Tieszen LL, Boutton TW, Tesdahl KG, Slade NG (1983) Fractionation and turnover of stable carbon isotopes in anmal tissues: implications for $\delta^{13} \mathrm{C}$ analysis of diet. Oecologia 57 : $32-37$

Vogel C, Eglinton B, Auret JM (1990) Isotope fingerprints in elephant bone and ivory. Nature $346: 747-748$

Zar JH (1984) Biostatistical analysis, 3rd edn. Prentice Hall, Upper Saddle River, NJ

Zug CR, Parham JF (1996) Age and growth in leatherback turtles. Dermochelys coriacea (Testudines: Dermochelyidaej: a skeletochronology analysis. Chelonian Conserv Biol 2(2):244-249

Submitted: December 17, 1997; Accepted: February 26, 1998 Proofs received from author(s): May 5, 1998 